\title{
Usefulness of lung biopsy in critically ill patients undergoing mechanical ventilation
}

\author{
J Marin-Corral', I Oliva, J Leache, L Claverias, V Blazquez, G Moreno, M Magret, M Bodi, C Villavicencio \\ From ESICM LIVES 2015 \\ Berlin, Germany. 3-7 October 2015
}

\section{Objectives}

To evaluate the clinical usefulness of lung biopsy in ventilated patients admitted to an Intensive Care Unit.

\section{Methods}

Retrospective descriptive study that included 16 ventilated patients admitted to the ICU, which underwent a lung biopsy between 2008 and 2013. Demographic data, reason for admission, comorbidities, APACHEII, SOFA, SAPS3, reason for biopsy, clinical data, laboratory results, bronchoalveolar lavage (BAL), radiological pattern and histology, were analyzed. Changes in treatment generated by these results and their impact on prognosis were also analyzed.

\section{Results}

The average age of the population was $60( \pm 13)$ years. $68.8 \%$ of patients were male. Most patients were admitted for severe CAP (62.5\%). The most frequent comorbidities were malignancy and immunosuppression (25\%) with APACHE $17( \pm 5)$ SAPS3 $57( \pm 14)$ and SOFA $5( \pm 2)$. The main reason for lung biopsy was nonresolving acute respiratory distress syndrome (ARDS, $56.3 \%$ ). $62.5 \%$ of biopsies were opened, $25 \%$ were transbronchial and $12.5 \%$ were obtained with transthoracic punction. Laboratory results and BAL were inconclusive and the most frequent tomographic pattern was alveolar damage and ground glass (56.2\%). The main results of biopsies were idiopathic interstitial disease (56\%), tumors (25\%) and other processes (19\%). In $55.5 \%$ of cases the histologic diagnosis led to changes in treatment (start corticosteroids or stop antibiotic). The most common complication related to the procedure was pneumothorax (25\%). Intra-ICU mortality was $50 \%$ and within patients who died, $75 \%$ had neoplastic disease and $25 \%$ had interstitial disease.

\section{Conclusions}

Open lung biopsy confirmed the diagnosis in all cases and caused a change in treatment in $50 \%$ of them. The most frequent diagnosis was idiopathic interstitial lung disease, which appears to have a better prognosis than neoplasic pathology. In the group of patients with nonresolving ARDS, Lung biopsy could be a useful and safe procedure to guide the treatment and prognosis.

Published: 1 October 2015

doi:10.1186/2197-425X-3-S1-A96

Cite this article as: Marin-Corral et al: Usefulness of lung biopsy in critically ill patients undergoing mechanical ventilation. Intensive Care Medicine Experimental 2015 3(Suppl 1):A96.
Submit your manuscript to a SpringerOpen ${ }^{\circ}$ journal and benefit from:

- Convenient online submission

- Rigorous peer review

- Immediate publication on acceptance

- Open access: articles freely available online

- High visibility within the field

Retaining the copyright to your article

\section{SpringerOpen ${ }^{\circ}$}

(c) 2015 Marin-Corral et al.; This is an Open Access article distributed under the terms of the Creative Commons Attribution License (http://creativecommons.org/licenses/by/4.0), which permits unrestricted use, distribution, and reproduction in any medium, provided the original work is properly cited. 